promising of the tin-bearing areas so far prospected lies in Eastern Transbaikal, but the recorded tonnages of proved ore are not large. Reports suggest that tin smelters may soon be operating in Yakutia and Tetiukhe, in Eastern Siberia. Unless tin substitutes are developed, however, it is inferred that the U.S.S.R. must continue to rely partly on imports of the metal. Valuable deposits of antimony ore have been discovered at Kadam Djai in the Kirghiz and in Central Siberia, and it seems justifiable to expect that Russia will be able to meet her own moderate peace-time needs of antimony.

Statistics for gold production are a State secret, but it is certain that the Union has adequate resources of this precious and enigmatic metal.

\section{Non-Metallic Minerals}

Russia's position with regard to many non-metallic minerals is stronger than that of any other country.

In recent years the U.S.S.R. has been the world's largest producer of erude magnesite. The Satka deposit, near Cheliabinsk in the Central Urals, alone yielded more than 800,000 tons of the mineral in 1937 ; including nearby deposits, the reserves are reputed to be about 250 million tons. Hitherto most of the output has been utilized for refractory purposes, but some magnesium metal is also manufactured from Satka ore. Although the production of metallic magnesium was less than 4 per cent of the world total in 1940, the potential output is enormous, for there are extensive supplies of raw materials from which the metal can be extracted, notably the rich carnallite $\left(\mathrm{KMgCl}_{3} \cdot 6 \mathrm{H}_{2} \mathrm{O}\right)$ deposits of Solikamsk in the Western Urals, brine from various salt lakes, and the Satka magnesites.

Russian geologists claim that the prospected phosphate rock deposits of the U.S.S.R. now exceed 60 per cent of the world's resources. Near Kirovsk, in the Kola Peninsula, remarkable bodies of apatite, discovered in 1926, have recently been yielding more than 2 million tons of ore annually, with reserves for another millennium. The principal phosphorite deposits occur in European Russia, in the regions of Kirov (Phosphoritnaya) and Moscow (Egorjevsk), but an extensive and favourably situated field near Aktiubinsk in North-west Kazakhstan is being developed to supply agricultural fertilizers for western Soviet Asia.

No details of mica production have been issued since 1935, when the Union held second place in world rank. The muscovite pegmatites of the MamaVitim area in Eastern Siberia and the Chupa Fjord district of Karelia, and the phlogopite veins of Slyudyanka at the western end of Lake Baikal, are doubtless capable of providing adequate supplies for domestic consumption. For many years the Russian output and export of asbestos has only been exceeded by that of Canada. The yearly production of chrysotile asbestos from the well-known Bazhenov field, near Sverdlovsk, is roughly 100,000 tons, the total reserves amounting to more than 30 million tons. It is unquestionably one of the largest and most productive asbestos fields in the world.

The region of Solikamsk, on the western slopes of the Urals, has long been known for its brines and salt works, but it was only after deep boring commenced in 1925 that the remarkable deposits of potassium and magnesium salts (sylvinite and carnallite) and the enormous masses of rock salt were thoroughly investigated over an area of some 700 square miles. Production started in 1932 and within five years the annual output had risen to more than two million tons of crude salts, and large quantities were being exported. Solikamsk reserves are claimed to represent about 80 per cent of the world's resources, consisting of 15,000 million tons of potash salts, 18,000 million tons of magnesium salts, and scores of thousands of millions of tons of rock salt. Even the famous Stassfurt deposits of Germany are dwarfed.

In 1938 Russia was among the leading producers of pyrite, with a tonnage approaching one million, derived chiefly from the Uralian cupriferous bodies (especially Degtiarsk) and from various coal mines. Expeditions to the Kara Kum Desert and the Gourdak Range in Turkmen territory, east of the Caspian Sea, have discovered huge supplies of native sulphur, quite comparable with the great Sicilian deposits. These Turkmen occurrences are likely to be the main future supply of sulphur, except in areas where it is being recovered during the treatment of sulphide ores.

Adequate resources of other minerals, such as graphite, fluorite and gypsum, are known to exist within the Union.

The development of mineral resources in the U.S.S.R. during the past fifteen years has far surpassed anything formerly achieved in a like period of the world's history. Sceptics may doubt the validity of some of the Russian estimates of ore reserves, but it should be recalled that vast territories still await detailed investigation and that the actual resources might well prove to exceed those now claimed. Despite the present marked deficiency in a few metals, notably tin and tungsten, it is reasonable to suppose that the U.S.S.R. will eventually become almost entirely self-supporting and may be able to export large quantities of coal, iron, petroleum, manganese, platinum, magnesite, phosphates, asbestos, potash and sulphur. The U.S.S.R., with her immense natural resources and man-power, has much to offer in the cause of world progress and welfare, and not least a share in her abundant mineral wealth.

\section{OBITUARIES}

\section{Prof. A. Ukhtomsky}

Those physiologists from Great Britain who had the good fortune to attend the International Congress of Physiology at Leningrad and Moscow in 1935 will remember the picturesque figure of Prof. Ukhtomsky and his novel and philosophic approach to the problems of nervous physiology. As successor to Wedensky, he had done much to develop the ideas of his brilliant teacher. It is with great regret that we now learn of his recent death in a message from Prof. K. Kekcheev addressed to the Physiological Society, on which the following notes are based.

Alexey Ukhtomsky was born in 1875 and for twenty years held the chair of physiology in the University of Leningrad, to which he was appointed on the death of his teacher, the well-known Russian physiologist Wedensky.

Ukhtomsky is known for his numerous researehes into the excitation inhibition of the central nervous system. In 1911 he established the principle of the 'dominant', according to which, given the presence of any excited point in the brain, other auxiliary excitations do not call forth the usual reflexes but serve to enhance the excitation of the given point. 
One of the most clearly demonstrated examples of the dominant is the substantial enhancement of the embracing reflex in male frogs at a certain season of the year when any part of the skin is excited. Several of Ukhtomsky's researches were devoted to the time factor and 'system history' in phenomena occurring in nerve tissue during excitation inhibition.

In recent years, Ukhtomsky was interested in the physiology of labour, and his laboratory, under the direction of his collaborator Prof. M. Vinogradov, was one of the centres of this science in the U.S.S.R.

The work of Ukhtomsky and his school was published chiefly in the Proceedings of the Physiological Institute of the University of Leningrad, of which he was editor, and in Educational Records of the University of Leningrad.

\section{Prof. K. N. Moss, O.B.E.}

Prof. Kenneth Nevilile Moss, professor of coal and metal mining in the University of Birmingham since 1922, died on October 20 at the early age of fifty-one. Prof. Moss was very active and successful in the direction of the Mining Department of the University, and was mainly responsible for the raising of $£ 100,000$ for developments in the Faculty of Science, of which for four years he was dean. A notable scheme which he carried through was the institution of a number of scholarships to attract public-school boys to the Mining Department.

Prof. Moss was educated at Queen Mary's School, Walsall, and the University of Birminghain. He had practical experience of mining in the Cannock Chase, South Yorkshire and North Staffordshire coalfields and was for a year organizer of mining education for Derbyshire. Among other positions which he had held, he was chairman of the Advisory Committee on Coal and Petroleum of the Mineral Resources Department of the Imperial Institute, president of the National Association of Colliery Managers, president of the South Staffordshire and Warwickshire Institute of Mining Engineers, and a member of council of the Institute of Mining Engineers.

During the War of 1914-18, Prof. Moss was captain and adjutant to the 59th Divisional R.E., was awarded the O.B.E. (Military Division) and twice mentioned in dispatches. The loss of his forceful personality will be severely felt by the University of Birmingham. He leaves a widow and four daughters.

$$
\text { G. A. Shakespear. }
$$

WE regret to announce the following deaths :

Prof. Alfred Baker, emeritus professor of mathematies in the University of Toronto, where he occupied the chair of mathematics from 1887 until 1919, who was president in 1915 of the Royal Society of Canada, on October 27, aged ninety-four.

Prof. J. N. Collie, F.R.S., emeritus professor of organic chemistry in the University of London, on November 1, aged eighty-three.

Prof. J. C. Schoute, emeritus professor of botany in the University of Groningen, president of the Sixth International Botanical Congress, aged sixty-five.

\section{NEWS and VIEWS}

\section{Educational Biology}

EMINENTLY sane, though occasionally somewhat diffuse, are Mr. Hugh Ramage's views on "Educational Biology" (Sch. Sci. Rev., No. 91 ; June, 1942). Emphasizing the key position of biology in any adequate scheme of education, he takes the unequivocal stand that educational biology should centre upon a study of the human organism. There are many biologists who refuse to accept this view, but the author cuts a good deal of the ground away from the feet of potential opponents by his recognition of the importance of studying organisms valuable in the illustration of principles. Mr. Ramage also trails his coat on the controversial topic of sex education, but he speaks very good sense, here as elsewhere. Very salutary is his endeavour to check the swing of the pendulum away from a mere study of cadaver, before it reaches the position of the unco-ordinated study of 'function' isolated from the organism that functions. Salutary, too, is his insistence on the need for attention in school to problems of variability and ecology. It is rather difficult to be certain from this paper whether the author's outlook is that of a holist or a dialectical materialist, and indeed the teleological implications of the statement that organisms form a "purposive" entity (albeit with inverted commas) give ground for suspicion that perhaps Mr. Ramage takes up no consistent philosophical position. But he poses clearly here many problems of educational method which should receive the attention of all teachers.

\section{Engineering in Agriculture}

IN his presidential address to the Institution of Civil Engineers delivered on November 3, Sir John Thornycroft pointed out that his work has been so closely connected with the Navy, and to a smaller extent with the Army, that he considered it inadvisable in present circumstances to talk about it, as has usually been done by presidents of the Institution. $\mathrm{He}$ has, however, taken a great personal interest in engineering in agriculture, and he devoted his address to that topic. From the earliest times the engineer has played a very important part in helping the agriculturist in irrigation, drainage, land reclamation, and in the provision of implements which enable men, with the aid of oxen and horses, to do so much more than was possible with the primitive hoe and mattock. The address dealt in detail with the prob. lems of land drainage, soil erosion, and the application of steam and internal-combustion engines to tractors and farming machinery-ploughs, machines for sowing seed in drills and for planting root crops and potatoes, and harvesting machines. The importance of research was emphasized and mention was made of the establishment by the Government of the Agricultural Machinery Development Board and of an Institute of Research in Agricultural Engineering. A very large home-grown sugar industry has been built up in Great Britain in recent years, and the British Sugar Corporation has contracts with more than 52,000 farmers, who provide 400,000 acres of the crop; the whole of the domestic sugar ration 